This item was submitted to Loughborough's Research Repository by the author.

Items in Figshare are protected by copyright, with all rights reserved, unless otherwise indicated.

Imperial myths between nationalism and communism: appropriations of imperial legacies in the north-eastern adriatic during the early cold war

PLEASE CITE THE PUBLISHED VERSION

http://dx.doi.org/10.1177/0265691411418750

PUBLISHER

SAGE Publications () the author

VERSION

AM (Accepted Manuscript)

LICENCE

CC BY-NC-ND 4.0

REPOSITORY RECORD

Mihelj, Sabina. 2019. "Imperial Myths Between Nationalism and Communism: Appropriations of Imperial Legacies in the North-eastern Adriatic During the Early Cold War". figshare. https://hdl.handle.net/2134/13206. 
This item was submitted to Loughborough's Institutional Repository (https://dspace.lboro.ac.uk/) by the author and is made available under the following Creative Commons Licence conditions.

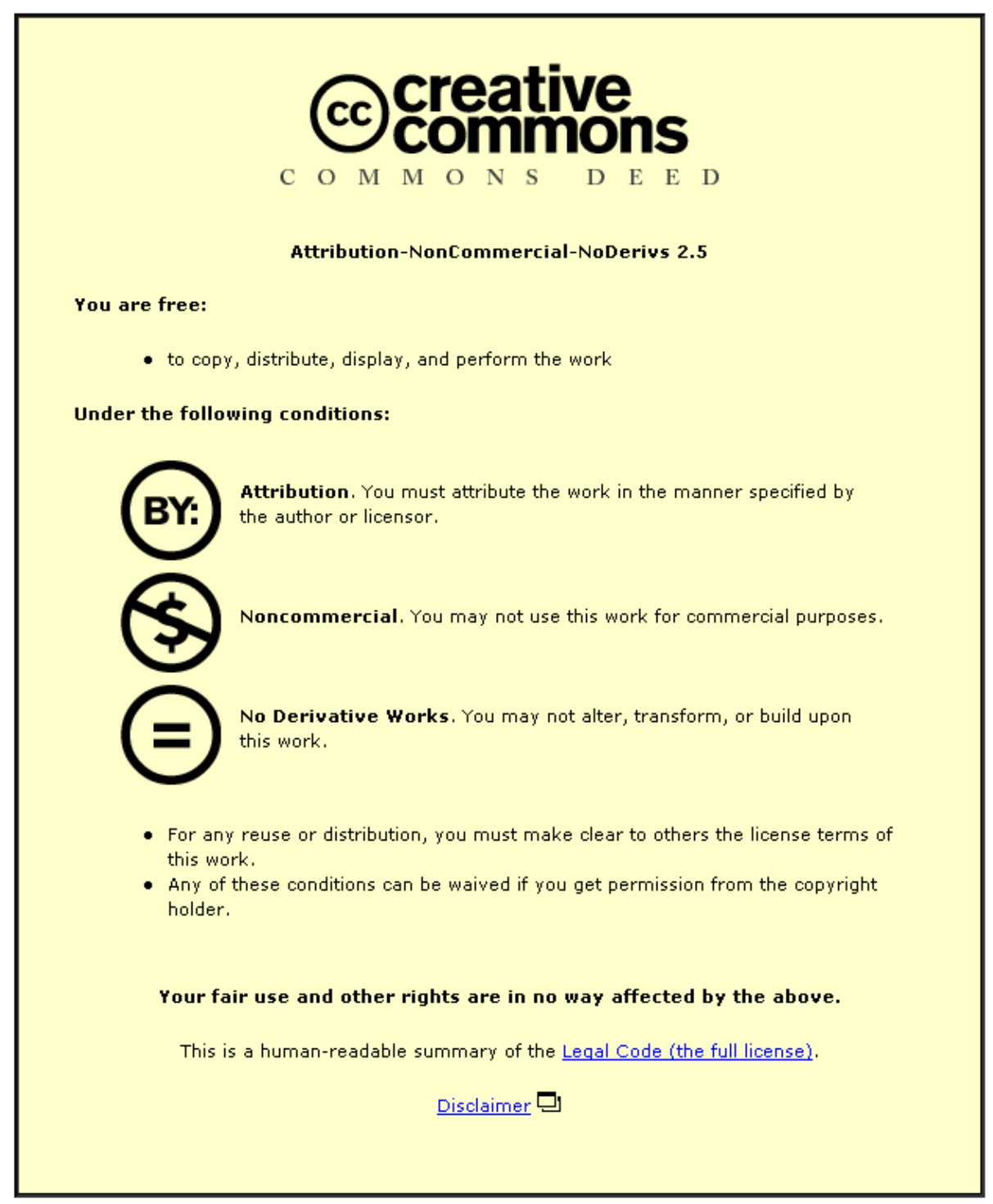

For the full text of this licence, please go to: http://creativecommons.org/licenses/by-nc-nd/2.5/ 
This is a pre-print version. Final version: Mihelj, S. (2011) 'Imperial Myths between Nationalism and Communism: Appropriations of Imperial Legacies in the Northeastern Adriatic during the Early Cold War', European Historical Quarterly 41(4): 634-56.

\title{
Imperial Myths between Nationalism and Communism: Appropriations of Imperial Legacies in the North-eastern Adriatic during the Early Cold War ${ }^{1}$
}

Sabina Mihelj

\begin{abstract}
In contemporary scholarly discussions, political uses of imperial pasts are typically associated with the rise of modern national states and nationalist principles of identity formation. Although clearly important, this approach can lead us to neglect the appropriations of imperial myths based on other types of ideological frameworks. In communist Eastern Europe, official representations of the past followed the imperatives of a historical-materialist vision of history, which, at least in its initial form, necessitated a rejection of both imperialism and nationalism. It is therefore reasonable to expect that communist appropriations of imperial legacies were significantly different from those found in Western Europe at the time. The article examines these different uses of imperial pasts - informed by either communism or nationalism or both - by focusing on the competing perceptions of imperial history and heritage at the Italo-Yugoslav border during the early Cold War.
\end{abstract}

Keywords: imperial myths, nationalism, communism, Italy, Yugoslavia

The last wave of nation-state-building, which swept away the multinational federations of Eastern Europe, prompted a renewed interest in nation-formation and nationalist myth-making. Much as their historical predecessors, these modern-day nation-builders frequently resorted to imperial legacies to buttress their territorial claims and demarcate themselves from their immediate neighbours. The nationalist elites of the newly independent national states across Eastern Europe often referred to divergent imperial legacies - Habsburg, Ottoman, Russian - to explain the persistence of cultural differences that separated them from their immediate neighbours, and presumably prevented them from functioning under a common political roof. ${ }^{2}$ Yet the prominence of nationalist myth-making in this recent wave of European state building

\footnotetext{
${ }^{1}$ This paper draws on research funded by the British Academy, grant reference SG-43957.

${ }^{2}$ See e.g. Graham Smith, Vivien Law, Andrew Wilson, Annette Bohr, Edward Allworth, Nationbuilding in the Post-Soviet Borderlands: The Politics of National Identities (Cambridge: Cambridge University Press, 1998); Pål Kolstø (ed.), Myths and Boundaries in South-Eastern Europe (London: Hurst \& Co., 2005).
} 
This is a pre-print version. Final version: Mihelj, S. (2011) 'Imperial Myths between Nationalism and Communism: Appropriations of Imperial Legacies in the Northeastern Adriatic during the Early Cold War', European Historical Quarterly 41(4): 634-56.

can lead us to neglect the constructions of imperial pasts based on alternative principles of sovereignty and identity-formation. For almost half a century, much of the European continent followed the imperatives of a historical-materialist vision of history, which, at least in its initial form, necessitated a rejection of both imperialism and nationalism. Although communist leaders regularly resorted to nationalist myths and symbols to boost their legitimacy, ${ }^{3}$ communist attitudes to imperialism followed ideological frameworks significantly different from those characteristic of nationalist myth-making.

This article aims to provide an insight into these diverse uses of imperial legacies by examining public representations of imperial history and heritage in the north-eastern Adriatic $^{4}$ during the early Cold War period. Over the past two millennia, the region had seen the rise and fall of the Roman, Byzantine, Frankish, Holy Roman, Venetian and Habsburg empires. This succession of imperial administrations left behind multiple imperial legacies, which provided fertile grounds for subsequent border disputes. From the nineteenth century onwards, the establishment of nationalizing states gave rise to territorial claims based on nationalist principles, which sought to make state borders coincide with cultural and ethnic boundaries. In an ethnically and culturally mixed area such as the north-eastern Adriatic, the imposition of nationalist principles was bound to trigger conflicting visions of identity and competing demands for the same territory. ${ }^{5}$ On the one hand, supporters of the newly formed Italian national state sought o appropriate the multicultural Venetian and Roman past of the north-eastern Adriatic as essentially Italian. On the other hand, Slovenian, Croatian and Yugoslav claims to the same territory rejected the imperial heritage as alien, or claimed selected elements as their own. Imperial legacies thus provided cultural

\footnotetext{
${ }^{3}$ E.g. David Brandenberger, National Bolshevism: Stalinist Mass Culture and the Formation of Modern Russian National Identity, 1931-1956 (Cambridge, Mass.: Harvard University Press, 2002); Bradley F. Abrams, The Struggle for the Soul of the Nation: Czech Culture and the Rise of Communism (Oxford: Rowman and Littlefield, 2004); Martin Mevius, Agents of Moscow: The Hungarian Communist Party and the Origins of Socialist Patriotism, 1941-1953 (Oxford: Oxford University Press, 2005).

${ }^{4}$ Among Italians, the region is known as the Julian Venetia (Venezia Giulia), while Slovenians and Croats refer to it as the Julian March (Julijska krajina).

${ }^{5}$ For an overview of the history of the region, with a focus on the impact of nationalist principles of identity- and border-formation, see Marina Cattaruzza, L'Italia e il confline orientale (Bologna: Il Mulino, 2007).
} 
This is a pre-print version. Final version: Mihelj, S. (2011) 'Imperial Myths between Nationalism and Communism: Appropriations of Imperial Legacies in the Northeastern Adriatic during the Early Cold War', European Historical Quarterly 41(4): 634-56.

materials to be selectively incorporated, whether by means of rejection or appropriation, into national myths of origins and national identity narratives. ${ }^{6}$

However, modern political uses of imperial legacies in the North-eastern Adriatic cannot be reduced to nationalist frames of reference alone. As Glenda Sluga argued, the ethnic and cultural complexities of the North-eastern Adriatic inspired principles of sovereignty border legitimation that perceived cultural diversity as an asset to be preserved rather than an obstacle to be eliminated. ${ }^{7}$ On the Italian side, and more broadly among Western observers, the Cold War confrontation gradually pushed these alternative solutions to border disputes in the region beyond the margins of acceptable, associating them with totalitarian ambitions of the communist East. On the other side of the Iron Curtain, however, models of sovereignty and identity marginalised in the West assumed centre-stage. At least initially, communist principles of sovereignty and identity formation were sharply opposed to nationalism and strongly rooted in notions of proletarian internationalism, and hence intrinsically compatible with culturally and ethnically diverse states.

We should note that at the same time, the West was undergoing a profound transformation which led to a progressive weakening of nationalist principles: defence of the nation was becoming subordinated to supranational integration and defence of 'the Free World' ${ }^{8}$ In socialist countries, almost the reverse was taking place: loyalty to the international alliance of working peoples was gradually giving way to national attachments, and internationalism itself was turning into a form of nationalism. ${ }^{9}$ Despite the constant emphasis on the incompatibility of communism and nationalism,

\footnotetext{
${ }^{6}$ For similar uses of imperial legacies in other post-imperial settings see e.g. L. Carl Brown (ed.), Imperial Legacy: The Ottoman Imprint on the Balkans and the Middle East (New York: Columbia University Press, 1996); Karen Barkey and Mark Von Hagen (eds.), After Empire: Multiethnic Societies and Nation-Building (Cambridge, Cambridge University Press, 1997).

${ }^{7}$ Glenda Sluga, The Problem of Trieste and the Italo-Yugoslav Border: Difference, Identity and Sovereignty in Twentieth-Century Europe (New York: SUNY Press, 2001).

${ }^{8}$ Perry Anderson, 'Internationalism: A Breviary,' New Left Review 14 (March-April 2002): 16ff.

${ }^{9}$ Ibid. The rise of communism itself of course owes a great deal to the manipulation of nationalist aspirations, condoned by both Marx and Lenin as an acceptable means of furthering the communist cause in prerevolutionary societies. Yet contrary to the expectations of Leninist national policy, communist revolutions proved unable to diffuse national sentiments. See Walker Connor, The National Question in Marxist-Leninist Theory and Strategy (Princeton: Princeton University Press, 1984).
} 
This is a pre-print version. Final version: Mihelj, S. (2011) 'Imperial Myths between Nationalism and Communism: Appropriations of Imperial Legacies in the Northeastern Adriatic during the Early Cold War', European Historical Quarterly 41(4): 634-56.

socialist countries proved unable to override the system of nation-states. ${ }^{10}$ Instead, ruling communist elites continued to draw on a mixture of communist and nationalist principles, presenting themselves simultaneously as the vanguards of the working classes as well as the vanguards of nations.

This article examines how these heterogeneous frameworks of reference - nationalist, transnationalist, and communist - affected the perceptions of imperial legacies in the North-eastern Adriatic in the post-War-War-II period. The analysis is limited to the years between 1947 and 1954, which allows us to examine the appropriations of imperial pasts at a point when the international alliance of socialist states was still rather firmly in place, as well as their subsequent transformation following Yugoslavia's expulsion from the Cominform in 1948. The time-frame also coincides with the period of existence of the Free Territory of Trieste (FTT), a short-lived political formation covering a patch of territory around the port-town of Trieste/Trst, ${ }^{11}$ claimed by both Italy and Tito's Yugoslavia. The post-World-War-II border dispute that resulted in the creation of FTT has a long and turbulent history, stretching back into the nineteenth century. ${ }^{12}$ In the years following World War II, the North-eastern Adriatic acquired a wider strategic significance: poised on the southern end of what came to be known as the Iron Curtain, its fate appeared too important to be left to Italy and Yugoslavia alone. After prolonged negotiations, most of the North-eastern Adriatic was carved up between the two neighbouring states, while the remaining patch of territory, comprising Trieste and its immediate surroundings, was declared a Free Territory. The FTT was divided into two zones, controlled respectively by the Allied Military Government (Zone A) and the Yugoslav army (Zone B). In line with the early Cold War politics of containment, Zone A came to function as the last

\footnotetext{
${ }^{10}$ Paul Shoup, 'Communism, Nationalism, and the Growth of the Communist Community of Nations after World War II,’ The American Political Science Review 56, No. 4 (1952) : 886-898.

${ }^{11}$ When first mentioned, all toponyms from the region are provided both in their Italian and in their Slovenian or Croatian variant. In all subsequent mentions, only the variant in what is now the majority language is used.

${ }^{12}$ For synthetic overviews see Cattaruzza, op. cit., and Rolf Wörsdörfer, Krisenherd Adria 1915-1955: Konstruktion und Artikulation des Nationalen im italienisch-jugoslawischen Grenzraum (Paderborn, München, Wien and Zürich: Ferdinand Schöningh, 2004).
} 
This is a pre-print version. Final version: Mihelj, S. (2011) 'Imperial Myths between Nationalism and Communism: Appropriations of Imperial Legacies in the Northeastern Adriatic during the Early Cold War', European Historical Quarterly 41(4): 634-56.

bulwark against Soviet expansionism, ${ }^{13}$ while at the same time, Zone B was becoming ever more incorporated into the Yugoslav economic, political and ideological system. ${ }^{14}$ After the electoral defeat of the Communist Party in Italy in 1948, and Yugoslavia's expulsion from Cominform later in the same year, the double-headed threat of Soviet expansion into Italian territory suddenly receded. In 1954, FTT was finally dismembered and the two zones annexed to the two neighbouring states.

To gain insight into local appropriations of imperial legacies between 1947 and 1954, the chapter examines discourses appearing in the major regional and minority newspapers published at the time, including Italian, Slovenian as well as Croatian ones. These comprise newspapers published in the Yugoslav part of the North-eastern Adriatic , including the Croatian daily Riječki list (1947-1954), later renamed into Novi list (1954-), the Slovenian bi-weekly Nova Gorica (1947-1953), later renamed into Primorske novice (1953-), and the Italian daily La Voce del Popolo (1945-). Together with the Slovenian bi-weekly Slovenski Jadran (1952-1963), published in Zone B, and the Slovenian minority daily Primorski Dnevnik (1945-), published in Zone A, most of these newspapers had their roots in clandestine antifascist, procommunist periodicals established during the Second World War. ${ }^{15}$ After the formation of Yugoslavia, they were all under close political control and supervision, and represented the identities and boundaries of the North-eastern Adriatic in broadly similar ways, mostly arguing for the annexation of FTT or at least the Yugoslavcontrolled Zone B to Yugoslavia. In contrast, La Voce Libera (1945-1949), Giornale di Trieste (1947-1954), and Giornale's successor Il Piccolo (1954-) - all published in Zone A - provide insight into Italian, pro-Western appropriations of imperial legacies at the time. Although affiliated to political groups at different ends of the political

\footnotetext{
${ }^{13}$ Raoul Pupo, Guerra e dopoguerra al confine orientale d'Italia (1938-1954) (Udine: Del Bianco Editore, 1999), 161.

${ }^{14}$ See Nevenka Troha, 'Ukrepi jugoslovanskih oblasti v conah B Julijske krajine in Svobodnega tržaškega ozemlja in Italijani na Koprskem,' Annales - Series historia et sociologia 10, No. 1 (2000): 203-216.

${ }^{15}$ See Bojan Pavletič, Primorski dnevnik 1945-1995 (Trst, Gorica and, Čedad: Družba za založniške pobude d.d., 1995); Branko Marušič ,'Povojni slovenski tisk,' in Zbornik Primorske - 50 let (Koper: Primorske novice, 1997); Božidar Novak, Hrvatsko novinarstvo u 20. stoljeću (Zagreb: Golden marketing - Tehnička knjiga, 1995), 344-347.
} 
This is a pre-print version. Final version: Mihelj, S. (2011) 'Imperial Myths between Nationalism and Communism: Appropriations of Imperial Legacies in the Northeastern Adriatic during the Early Cold War', European Historical Quarterly 41(4): 634-56.

spectrum, ${ }^{16}$ both newspapers unequivocally supported the annexation of Trieste to Italy, and represented the voices of those Triestines who 'recognised themselves in [...] the Western, Atlantic, and European camp'. ${ }^{17}$ While the sample is not exhaustive, it does cover the most widely distributed newspapers in the region, ${ }^{18}$ and thus also the most widespread appropriations of imperial pasts circulating in the public realm at the time.

\section{La Voce Libera, Giornale di Trieste and Il Piccolo: Imperial pasts as roots of}

\section{Italian civiltà and Western democracy}

The imperial legacies of Rome and Venice historically played a paramount role in Italian perceptions of the north-eastern Adriatic and of the Balkan Peninsula as a whole. Narratives of uninterrupted continuity stretching back to the times of the Roman Empire formed a crucial part of the Italian myth of origins, and served as the basis for irredentist claims to the north-eastern Adriatic. ${ }^{19}$ In the twentieth century, the myth of Rome became one of the pillars of Fascist doctrine,${ }^{20}$ and again reinvigorated Italian territorial pretensions in Istria and Dalmatia. Perceptions of the Venetian heritage of the north-eastern Adriatic served a similar purpose. Advocates of Italian territorial claims to Dalmatia participating at the Paris peace conference in 1919 used

\footnotetext{
${ }^{16}$ La Voce Libera was affiliated to the Venezia Giulia National Liberation Committee (Comitato di Liberazione Nazionale di Venezia Giulia), an anti-fascist, left-leaning organisation rooted in the proItalian antifascist struggle in the region. Giornale di Trieste, on the other hand, was in direct ideological and editorial continuity with the (in)famous daily Il Piccolo, which was known for its support to the Fascist cause. Although declaratively distancing itself from the far right, and leaning towards the political programme of Christian Democrats (Democrazia Christiana), Giornale di Trieste continued to perpetuate some of the core irredentist and Fascist arguments. See Luciano Becker, Roberto de Rosa and Silvano Benvenuti, 'La Voce Libera,' and Cesare Vetter, 'Il Giornale di Trieste,' both in Nazionalismo e neofascismo nella lotta politica al confine orientale 1945-75 (Trieste: La Editoriale Libreria, 1977), 27-61 and 112-142 respectively.

${ }^{17}$ Guido Botteri (ed.), Un secolo un giornale: Il Piccolo, 1881-1981 (Trieste: Società Editrice Triestina, 1981), 43.

${ }^{18}$ Other potentially interesting sources include the independentist daily Corriere di Trieste (19451958), which regularly invoked the Habsburg myth to harness support for the continued existence of FTT, the pro-Soviet newspapers such as the official outlet of the regional branch of the Italian Communist Party, Il Lavoratore (1945-1964) and its Slovenian counterpart Delo (1949), and the Slovenian weekly Demokracija (1947-1963), tied to the Catholic and liberal fractions within the Slovenian minority in Zone A.

${ }^{19}$ Gino Bandelli, 'Per una storia del mito di Roma al confine orientale: Istri e Romani dell'età dell'irredentismo,' Quaderni Giuliani di storia 15, No 1 (1994): 163-175.

${ }^{20}$ Romke Visser, 'Fascist Doctrine and the Cult of the Romanità,' Journal of Contemporary History 27 (1992): 5-22.
} 
This is a pre-print version. Final version: Mihelj, S. (2011) 'Imperial Myths between Nationalism and Communism: Appropriations of Imperial Legacies in the Northeastern Adriatic during the Early Cold War', European Historical Quarterly 41(4): 634-56.

references to the Venetian past of the region to buttress their demands. ${ }^{21}$ Throughout the 1920s, various public events and cultural products presented the north-eastern Adriatic as an inalienable part of the 'three Venices' (tree Venezie), i.e. historical Venetian provinces and therefore allegedly integral parts of modern-day Italy. ${ }^{22}$

This emphasis on the imperial and ancient heritage of the north-eastern Adriatic is not unique to Italy. It coincides with other Western images of the eastern Adriatic coast and the wider Balkan Peninsula as heirs of ancient civilisations. ${ }^{23}$ Architecture in particular played a paramount role in these perceptions, functioning as a material proof of the ancient past: Roman amphitheatres and arches, Venetian churches and houses were regularly presented as material remnants of ancient glory. ${ }^{24}$ However, unlike other Western perceptions, Italian images of the eastern Adriatic coast normally also used these remnants to buttress claims about the essential Italianness of the region. Large-scale excavations of Roman ruins taking place across Italy in both the late nineteenth and the early twentieth centuries formed a physical counterpart to the symbolic 'excavation' of what was perceived as Italy's own glorious past. In line with this alleged continuity, the uncovering of Roman ruins in Trieste functioned as a proof of city's Italianness, and thus of Italy's historic right to the city. The ancient ruins along the eastern Adriatic coast, such as the Roman amphitheatre in Pula/Pola in Istria and the Diocletian's Palace in Split/Spalato in Damatia served similar purposes.

Besides functioning as a crucial reference point for Italian claims to the eastern Adriatic coast, the Venetian era also gave rise to an influential legacy of perceptions, which were incorporated into Italian nationalist discourse and later became a crucial part of the Fascist doctrine. At the hart of this legacy of perceptions lies the notion of civiltà, which conveniently blends the modern ideas of culture, civilisation and civility. In the ideological universe of Enlightenment Venice, the eastern shore of the

\footnotetext{
${ }^{21}$ Larry Wolff, Venice and the Slavs: The Discovery of Dalmatia in the Age of Enlightenment (Stanford: Stanford University Press, 2001), 353-355.

${ }^{22}$ Maura Hametz, Making Trieste Italian, 1918-1954 (Royal Historical Society, 2005), 92-93.

${ }^{23}$ John B. Allcock, 'Constructing the Balkans,' in Black Lambs and Grey Falcons: Women Travellers in the Balkans, edited by John B. Allcock and Antonia Young (Bradford: Bradford University Press, 1991), 181-189.

${ }^{24}$ Ibid., 181-182.
} 
This is a pre-print version. Final version: Mihelj, S. (2011) 'Imperial Myths between Nationalism and Communism: Appropriations of Imperial Legacies in the Northeastern Adriatic during the Early Cold War', European Historical Quarterly 41(4): 634-56.

Adriatic was poised mid-way between barbarism and civilisation, and as such called for an enlightened intervention of Venetian civiltà. ${ }^{25}$ The civilising mission was envisaged as spreading from the urban, Italian-speaking coastal settlements into the rural hinterland, mostly populated by the supposedly lazy, irrational and ferocious 'Morlacchi' - a now non-existent category referring to populations speaking Slavic languages. ${ }^{26}$

In the nineteenth century, the notion of the enlightening, assimilatory civiltà became one of the founding stones of Italian national identity, and gradually assumed racist overtones as well, albeit initially of a cultural rather than biological kind. In the eyes of Italian nationalists, nothing prevented 'Slavs' from becoming civilised, yet they could do so only by embracing Italian civilisation or culture. ${ }^{27}$ In the twentieth century, this racialised form of the notion of civiltà was incorporated the Fascist perception of Italy's imperial past and its present mission. Fascists often spoke of Dalmatia, as well as the north-eastern shore of the Adriatic Sea, as a land in need of being civilised from the Italians, or singled out particular cities in Dalmatia as superior to other towns that were permeated by barbarism, low levels of hygiene, and, more generally, 'balkanism'. ${ }^{28}$ The aristocracy of the 'new' Fascist civilisation was believed to be morally responsible for saving humanity, including the inhabitants of the Balkans, from the combined threats of democracy, communism and Jewish conspiracy, thereby also securing the 'vital space' for the expansion of the Fascist

\footnotetext{
${ }^{25}$ Ibid., 324ff.

${ }^{26}$ Ibid., 132-138. The roots of Venetian contempt for inhabitants of the eastern shore of the Adriatic may go as far as the ancient Roman and Greek perceptions of ancient inhabitants of this region, the Illyrians, as 'savage' and 'barbarian'. According to John J. Wilkes, these ancient stereotypes may have contributed to the lasting neglect for Illyrians in most versions of ancient history. John J. Wilkes, The Illyrians (Oxford: Blackwell, 1992), 4-5.

${ }^{27}$ Pamela Ballinger, "Authentic Hybrids" in the Balkan Borderlands', Current Anthropology 45, No. 1 (2004): 34-36; Glenda Sluga, 'Narrating Difference and Defining the Nation in Late Nineteenth and Early Twentieth Century 'Western' Europe,' European Review of History 9, No. 2 (2004): 194-195. ${ }^{28}$ Wolff, op. cit., 355; Glenda Sluga, 'Identità nazionale Italiana e fascismo: alieni, allogeni $\mathrm{e}$ assimilazione sul confine nord-orientale italiano,' in Nazionalismi di frontiera: Identità contrapposte sull' Adriatico nord-orientale 1850-1950, edited by Marina Cattaruzza (Soveria Mannelli: Rubbettino, 2005), 171-202.
} 
This is a pre-print version. Final version: Mihelj, S. (2011) 'Imperial Myths between Nationalism and Communism: Appropriations of Imperial Legacies in the Northeastern Adriatic during the Early Cold War', European Historical Quarterly 41(4): 634-56.

New Order. ${ }^{29}$ These arguments served to justify increasingly ruthless forms of Italianisation of Slovenians and Croatians in the region. ${ }^{30}$

Elements of imperial legacies outlined in previous paragraphs were regularly appearing on the pages of both La Voce Libera and Giornale di Trieste, as well as in Giornale's successor Il Piccolo. All three newspapers shared an unambiguous commitment to the Italian national cause and supported Italian territorial claims to Istria and Dalmatia. The opening issue of Giornale di Trieste presented the daily as 'above all an Italian newspaper', which intends to 'correspond with the exigencies of a population that is largely Italian in terms of culture, language and sentiment' ${ }^{31}$ The understanding of Italianness as an attribute linked to culture, language and sentiment - rather than ethnic or racial descent - clearly fits the model of assimilatory Italian nationalism established in the nineteenth century and exploited by fascism. At the same time, it also provides the basis for Giornale's belief that the 'new territorial arrangement of Trieste' is merely temporary, potentially open to revision once the post-war confusion has settled down. The opening editorial of La Voce Libera followed a similar ideological pattern. By writing about 'the love we bring to our Trieste, to the tormented Julian lands and to the whole of Italy', it clearly signalled its belief in the Italian character of both Trieste and the north-eastern Adriatic as a whole. ${ }^{32}$ In line with this belief, the presence of the Yugoslav administration was seen as 'temporary', and the Yugoslav solution to the Trieste problem was described as 'unilateral, clearly opposed to designations of history and culture'. In a manner characteristic of Italian nationalism since the late nineteenth century, La Voce was thus using culture and history to delegitimate alternative territorial claims to the region - in this case claims put forward by Tito's Yugoslavia.

As several articles published in the three newspapers made clear, the 'designations of history and culture' referred to in the opening issue of La Voce were rooted in the

\footnotetext{
${ }^{29}$ Davide Rodogno, 'Italian Soldiers in the Balkans: The Experience of the Occupation (1941-1943),' Journal of Southern Europe and the Balkans 6, No. 2 (2004): 125-144.

${ }^{30}$ For a brief overview of assimilatory policies in the region under fascism see Cattaruzza, op. cit., 168181.

${ }^{31}$ Giornale di Trieste, 6 March 1947, 1.

${ }^{32}$ La Voce Libera, 23 July 1945, 1.
} 
This is a pre-print version. Final version: Mihelj, S. (2011) 'Imperial Myths between Nationalism and Communism: Appropriations of Imperial Legacies in the Northeastern Adriatic during the Early Cold War', European Historical Quarterly 41(4): 634-56.

perceived continuity that linked modern-day Italy to the Roman and Venetian empires. These perceptions of imperial legacies came particularly clearly to the fore in the reporting on developments in Dalmatia and parts of Istria under Yugoslav rule. In these reports, various cultural traits, especially architectural ones, played the dual role noted by Pamela Ballinger in her analysis of Italian exile memories and perceptions of Istria: they functioned both as the enduring imprint of Italian civiltà, and as a symbol of its destruction and decay caused by hostile invaders. ${ }^{33}$ Depictions of cultural remnants of glorious Roman and Venetian pasts were thus regularly contrasted with the foreign, alien, and hence illegitimate presence of Yugoslavs. ${ }^{34}$ In the eyes of Il Piccolo, something completely ludicrous was taking place in the part of the north-eastern Adriatic belonging to Yugoslavia: 'in a land whose Roman, Venetian and Italian configuration and its unbroken progression of a two-thousandyear old civilisation could only be changed by a tectonic shift which would swallow it', everything was being done to 'erase' Italian culture. ${ }^{35}$ This statement leaves little doubt as to where the capital proof of the Italianness of the region lies: it lives in the indelible, two-thousand years long presence of Roman and Venetian legacies, now being destroyed by the Yugoslavs.

Giornale shared a very similar attitude towards Yugoslav presence in the region. In a characteristic comment accompanying the photo reportage from Pula, the town's Roman amphitheatre was used to symbolise the towering and timeless presence of Italianness, and as such provided a stark contrast to what was presented as a pitifully small and lonely group of pro-Yugoslav protesters:

\footnotetext{
On Monday September 15, at 14:30, a lens captured this snapshot in Pula: the passing, in the middle of a deserted city, of a thin grouplet of proYugoslav 'campaigners', who came to the city to greet Pula on the occasion of Tito soldiers' holiday. With a magnifying lens we counted 42 persons: 17 men, 13 women, 12 children, and 4 flags, 2 bikes and one accordion. All around emptiness, no spectators; silence, desolation.
}

\footnotetext{
${ }^{33}$ Ballinger, History in Exile, op. cit., $175 \mathrm{ff}$.

${ }^{34}$ Similar contrasts can be found in Western representations of luxurious material objects used in the Balkans. As a rule, inhabitants of the Balkans were presented as uncivilised barbarians, unable to use such objects properly. See Božidar Jezernik, Wild Europe: The Balkans in the Gaze of Western Travellers (London: SAQI, in association with the Bosnian Institute, 2004), 43-46.

${ }^{35}$ Il Piccolo, 27 Oct 1954, 1.
} 
This is a pre-print version. Final version: Mihelj, S. (2011) 'Imperial Myths between Nationalism and Communism: Appropriations of Imperial Legacies in the Northeastern Adriatic during the Early Cold War', European Historical Quarterly 41(4): 634-56.

Something, yes, was overlooking the little, confused caravan, almost

crushing it: her majesty the Arena. The past was watching from its empty eye sockets, a timeless past: the Italian eternity of the region. ${ }^{36}$

Such images of emptiness and desolation were a standard element of Giornale's depiction of Istrian and Dalmatian towns and cities, and were often accompanied by emotional, nostalgic recollections of the vibrant, joyful golden age of Italy's presence in the region. The land left behind by the exiles was presented as 'an almost deserted country, emptied, dead. No flag on the windows of houses, taverns and inns deserted'. ${ }^{37}$ Once the exile is over, claimed another article, 'all that will be left will be the pine forests, deserted suburbs, lost valleys, where the autumn sky is stretched across the sunset, red and bloody like our mutilated country, ${ }^{38}$

Similar rhetorical constructs of past and present, joy and desolation, life and death, could be found also in La Voce. A photo-reportage from Zara/Zadar, one of the major urban settlements on the Dalmatian coast, was composed exclusively of images of ruins, decaying buildings and empty streets. ${ }^{39}$ As one of the graphically most prominent subtitles suggested, the images represented a 'Venetian city', which is 'dying in a long and grey agony'. According to the reporter, the city looked 'as if being recently bombarded, with the physiognomy of its buildings deranged'. As the rest of the reportage made clear, that physiognomy was Venetian, and its survival was allegedly dependent on the continued presence of Italy and Italians in the region. Without that presence, without the 'activity of an industrious, noble population', Zadar's 'lively shores, its hard-working factories, its Venetian lanes' were no longer there, and had no hope of returning. Abandoned by Italy and Italians, the remains of the Venetian architecture were, in the eyes of the reporter, only lifeless shells emptied of their true content: 'Everything in this beautiful Venetian city is eviscerated. Only the bell tower is standing erect, reaching to the skies, like a huge forefinger that seems to be invocating something that is no longer there: Italy.' Following the model employed in several other articles, the reportage thus used Venetian architecture as

\footnotetext{
${ }^{36}$ Giornale di Trieste, 18 September 1947, 1.

${ }^{37}$ Giornale di Trieste, 14 September 1947, 1.

${ }^{38}$ Giornale di Trieste, 16 September 1947, 1.

${ }^{39}$ La Voce Libera, 14 June 1948, 3.
} 
This is a pre-print version. Final version: Mihelj, S. (2011) 'Imperial Myths between Nationalism and Communism: Appropriations of Imperial Legacies in the Northeastern Adriatic during the Early Cold War', European Historical Quarterly 41(4): 634-56.

the symbol of Zadar's true essence, namely Italianness. Bereft of its enlivening and industrious spirit, the city was bound to decay and die.

As evident from the above, neither La Voce nor the Giornale or its successor Il Piccolo allowed for the prospect of Roman and Venetian heritage being shared and kept alive by non-Italian inhabitants of the region. Their depictions of Istrian and Dalmatian towns clearly signalled that the true heirs of Roman and Venetian legacies were those who left and sought refuge in Italy: 'The exiles [...] remember the work of defence carried out for thousands of years by Istrians and Dalmatians in the name of Italy, in lands now ceded to the foreigner' ${ }^{40}$ The only hope left was tied to the few Italians staying in the region, 'brothers' who, as the then Italian president put it in one of his speeches, 'are being unjustly torn away from the arms of [their] ancient mother' ${ }^{41}$ In contrast, the Slavic inhabitants of Istria and Dalmatia were regularly denied any claim to 'autochthonous' presence on the eastern shores of the Adriatic, and were instead presented strictly as 'foreigners' and 'newcomers'. The symbolic appropriations of these remains by the Yugoslav authorities were ridiculed and seen as a further confirmation of the unjustness of Yugoslav rule in the region. For example, when the Yugoslav communist authorities, upon first entering Pula, covered the ancient Roman Arch of the Sergii in long red drapes, this was interpreted as a sign of their inability to face the true splendour of Roman monuments - a splendour that, implied the commentator, was reminding them of the true nature of the town. ${ }^{42}$

Perceptions of imperial legacies discussed so far represent variations on Italian nationalist imagery established well before World War II. However, while drawing on established nationalist perceptions, La Voce and Giornale were also engaged in refashioning them according to the exigencies of Cold War politics. This rhetoric was increasingly giving pride of place to supranational allegiances rather than national interests alone. The Italians of the north-eastern Adriatic were thus seen not only as bearers of a two-thousands-years-old Italian civiltà, but also as defenders of democracy and freedom of the West, fighting the oppression and barbarity of the

\footnotetext{
${ }^{40}$ Giornale di Trieste, 18 September 1947, 1.

${ }^{41}$ Quoted in Giornale di Trieste, 16 September 1947, 1.

${ }^{4}$ Giornale di Trieste, 21 September 1947, 1.
} 
This is a pre-print version. Final version: Mihelj, S. (2011) 'Imperial Myths between Nationalism and Communism: Appropriations of Imperial Legacies in the Northeastern Adriatic during the Early Cold War', European Historical Quarterly 41(4): 634-56.

communist, totalitarian East. The old opposition of the civilised coast and the untamed hinterland, of Italian civiltà and the barbaric Slavs of the Balkans, was now weaved into the dichotomy of the liberal West and the illiberal East. Hence, 'the dear cities from Zadar to Pula, from Fiume/Rijeka to Parenzo/Poreč' were not only torn away from they Italian 'Fatherland', but at the same time also 'disappeared from the scope of Western civilisation, falling into a night without history', ${ }^{43}$ and were 'suffering under the yoke of Yugo-communist barbarism'. ${ }^{44}$

However, in the eyes of La Voce and Giornale, 'the Yugo-communists' where not the only threat that the Italian civiltà and the democratic civilisation of the West were facing in the north-eastern Adriatic. Occasionally, the Allied administration of Zone A would join the ranks of enemies as well. Similarly as hostile depictions of Yugoslavs, these representations occasionally drew on Italy's Roman and Venetian legacies, as well as on the notion of Italian civiltà. On one occasion, Giornale accused the Allied administration of disregarding all civil norms, and what is more doing so in 'a city that was among the most civilised ones in Italy and Europe'. ${ }^{45}$ In a similar vein, an editorial published in La Voce Libera questioned the policies adopted by the Allied forces in the region, and claimed that true democratic liberties could be secured only with the return of the FTT to Italy. ${ }^{46}$ At the very least, argued another article, Italy should be involved in the administration of justice in the FTT. The main reason for this, reckoned the commentator, lay in Italy's Roman heritage, in the fact that Italy 'gave the world the Roman law'. ${ }^{47}$

Allies' apparent disrespect for Italian civiltà was particularly loudly emphasised in Giornale's reporting of mass demonstrations and incidents of violence in the autumn of 1953. The demonstrations were sparked by an announcement, issued jointly by the United States and Britain on October 8, in which the two Allies informed the parties involved that they intend to withdrawn their troops from Zone A of the FTT and hand the administration over to Italy. The pro-Italian part of the population, cheer-led by

\footnotetext{
${ }^{43}$ Giornale di Trieste, 26 October 1954, 11.

${ }^{44}$ Giornale di Trieste, 9 October 1953.

${ }^{45}$ Giornale di Trieste, 1 October 1947, 1.

${ }^{46}$ La Voce Libera, 1April 1947, 1.

${ }^{47}$ La Voce Libera, 1 April 1947, 1.
} 
This is a pre-print version. Final version: Mihelj, S. (2011) 'Imperial Myths between Nationalism and Communism: Appropriations of Imperial Legacies in the Northeastern Adriatic during the Early Cold War', European Historical Quarterly 41(4): 634-56.

Giornale di Trieste, greeted the prospect of the arrival of Italian troops with excitement, organising mass displays of national loyalty. The demonstrations that escalated in early November provoked repressive measures on the side of the Allied Military Government, and resulted in bloodshed. ${ }^{48}$ Giornale was outraged at the response of the Allied administration. What was at stake in the incidents, argued one of the editorials, were 'the honour of a western city that prides itself on being Christian, the honour of our Allies [...], the salvation of a democratic Europe' ${ }^{49}$ The authorities, argued another article published in Giornale, should be able to recognise who the real enemy is: on the one hand, there is 'a nation that, for the first time, is being faced with civilisation, and has to put up with an atheo-communist tyranny', i.e. the Slavs, and on the other hand, there is 'a nation that, for the greatest part, created this same civilisation and diffused it across the world', i.e. the Italians. ${ }^{50}$ The true lines of division as seen by Giornale di Trieste are clear: a pious, Christian, civilised and democratic nation is being threatened by an atheist, uncivilised nation and its totalitarian regime. All the Italian protesters were guilty of, claimed another article, was 'love for Italy in the ideological tradition of Giuseppe Mazzini, who was the first one who hoped for a union of peoples and for the birth of a Europe of democratic and liberal values which the West has now risen to defend' ${ }^{51}$ Not only is the Fascist past completely neglected; Italian nationalism itself is presented as the cradle of European democracy and liberalism.

In this context, the Allied presence in the city assumed the position that had previously been occupied by Italy’s foremost imperial enemy: the Austro-Hungarian Empire. Similarly as the Austro-Hungarian Empire, the Allies were now seen as working in the interests of the Slavs. ${ }^{52}$ In line with this parallel, those who died or were injured in the violent clashes with the police were regarded as heroes, worth of

\footnotetext{
${ }^{48}$ Bogdan C. Novak, Trieste, 1941-1954: The Ethnic, Political and Ideological Struggle (Chicago and London: University of Chicago Press, 1970), 418-448; Roberto G. Rabel, Between East and West: Trieste, the United States and the Cold War, 1941-1954 (Durham and London: Duke University Press, 1988), 150-152.

${ }^{49}$ Giornale di Trieste, 6 November 1953, 1.

${ }^{50}$ Giornale di Trieste, 6 November 1953, 2.

${ }^{51}$ Giornale di Trieste, 8 November 1953, 1.

${ }^{52}$ For a discussion of the close link between anti-Austrian and anti-Slav sentiments in Italian nationalism see Cattaruzza, op. cit., 46-47.
} 
This is a pre-print version. Final version: Mihelj, S. (2011) 'Imperial Myths between Nationalism and Communism: Appropriations of Imperial Legacies in the Northeastern Adriatic during the Early Cold War', European Historical Quarterly 41(4): 634-56.

being commemorated together with those who died resisting Habsburg rule. Perhaps, argued Giornale, 'we will soon be able to ask our municipal authorities to add their names to the glorious list of those who fell for the liberty of Trieste and the unity of the Fatherland'. ${ }^{53}$ At the same time, the memories of Italian victory in the battle of Vittorio Veneto, which marked the final dissolution of the Austro-Hungarian Empire, was used to fuel the perception of the current settlement of borders in the northeastern Adriatic as merely temporary. Sooner or later, claimed Giornale, a new Vittorio Veneto was bound to occur, redrawing the eastern border of Italy to fit the demands of Italian culture and history. Not even the powers of Habsburg Vienna, argued an editorial published in Il Piccolo, 'were able to damage the centuries-long truth', i.e. the truth of the essential Italianness of the Adriatic region. 'We,' declared the editorial, 'believe religiously in the powers of history. [...] The Italian civiltà in the Adriatic was not a mis-en-scène of a people drunk of its victory, but an indestructible product of a centuries-long stratification, which always held up to adversities'. Therefore, the Italians left abandoned on the other side of the Iron Curtain should keep faith, since nothing could prevent 'the flag of the fatherland from returning to shine brightly where it was planted by the heroes of Vittorio Veneto' ${ }^{54}$ In the eyes of Il Piccolo, the border dispute between Italy in Tito's Yugoslavia was thus simply yet another chapter in Italy's perennial struggle against territorial pretensions of its eastern neighbours.

\section{The pro-Yugoslav press: between communist and nationalist rejections of imperial legacies}

On the Yugoslav side, imperial legacies were dealt with in a significantly different manner. In line with anti-imperialist convictions of international communism prevalent at the time,${ }^{55}$ the multiple imperial legacies that left their imprints in Yugoslav territories were not glorious models to be emulated in the present, but dark, oppressive forces whose heritage should be erased. Together with the "new imperialist

\footnotetext{
${ }^{53}$ Giornale di Trieste, 7 November 1953, 1.

${ }^{54}$ Il Piccolo, 26 October 1954, 1.

${ }^{55}$ Anthony Brewer, Marxist Theories of Imperialism: a Critical Survey (London: Routledge, 1990), esp. 116-135.
} 
This is a pre-print version. Final version: Mihelj, S. (2011) 'Imperial Myths between Nationalism and Communism: Appropriations of Imperial Legacies in the Northeastern Adriatic during the Early Cold War', European Historical Quarterly 41(4): 634-56.

forces of the West', these legacies formed an integral part of 'the forces of the past' or 'retrograde elements' that Yugoslavia had chosen to overcome by embarking on a socialist revolution. ${ }^{56}$ Underpinning this rejection of the past was a narrative of modernity that reversed some of the core ideological foundations of westocentric narratives found in La Voce Libera and Giornale di Trieste. This pro-Yugoslav narrative still retained the characteristic opposition between the modern, civilised Self and the backward, primitive Other ${ }^{57}$ - now appearing in the form of an antagonism between 'progressive' and 'retrograde' forces - yet rejected the idea that civilisation and progress are rooted in a glorious past, be it imperial or of another kind. Tradition was not something to be nourished and preserved, but an obstacle to revolution, 'weighing like a nightmare on the brains of the living' and preventing them from revolutionising the world without 'conjuring up the spirits of the past' ${ }^{58}$ Modelling the present and future on an imperial past and constructing a myth of origin stretching back to antiquity, as Italian nationalism did, was therefore out of question. Instead, progress was to be oriented strictly to the future, and necessitated a myth of origins centred on a revolutionary break with the things past, including a break with imperial legacies.

For pro-Yugoslav newspapers, the annexation of most of Istria and later also Zone B to Yugoslavia represented exactly such a break. If, in the eyes of La Voce Libera and Giornale, the dismemberment of FTT pushed Istria into a 'darkness without history', a period of destruction, death, and barbarism, pro-Yugoslav outlets painted the same event as a symbolic rebirth, a beginning of 'new times', full of hope and light. With the annexation of Koper/Capodistria to Yugoslavia, wrote one article, 'the sun finally began to shine above this town', and the annexation was accompanied by 'hopes for the beginning of new times'. ${ }^{59}$ The very same Venetian and Roman legacies that for

\footnotetext{
${ }^{56}$ As Dejan Jović argued, the past formed one of the main Others in Yugoslav identity narratives. See Dejan Jović 'Communist Yugoslavia and Its 'Others',' in Ideologies and National Identities: The Case of Twentieth century Southeastern Europe, edited by John Lampe and Mark Mazower (Budapest: CEU Press, 2004), 278-280.

${ }^{57}$ This opposition is at the root of modern narratives of identity and difference. See Michael Pickering, Stereotyping (Basingstoke: Palgrave Macmillan, 2001), 51.

${ }^{58}$ Karl Marx, 'The Eighteenth Brumaire of Louis Bonaparte,' in Karl Marx, Selected Writings, edited by Lawrence H. Simon (Indianapolis: Hackett Publishing, 1994), 187.

${ }^{59}$ Primorske novice, 26 November 1954, 1-2.
} 
This is a pre-print version. Final version: Mihelj, S. (2011) 'Imperial Myths between Nationalism and Communism: Appropriations of Imperial Legacies in the Northeastern Adriatic during the Early Cold War', European Historical Quarterly 41(4): 634-56.

La Voce Libera and Giornale functioned as the basis of Italian civiltà and the continuing prosperity of the region were here seen exclusively as one among the many 'dark forces of the past', responsible for prolonged 'enslavement' and 'oppression'. An article published in Slovenski Jadran for example described the fate of a village under various 'occupiers', including the Venetian and Habsburg Empires, and glorified 'the centuries-old struggle' of local inhabitants against their 'oppressors'. ${ }^{60}$

The various imperialist Others, and particularly so Fascist Italy, were also the ones to be blamed for the poor economic and social conditions in the north-eastern Adriatic, as well as Yugoslavia as a whole. As one article put it: 'It wasn't easy to take over the heritage of Fascist Italy, which was oppressing the people [...] in some places as much as $60 \%$ of the population was illiterate, all thanks to a state which is boasting a cultural tradition going back two thousand years'. ${ }^{61}$ 'Our working people', claimed another article, 'were consciously and calculatingly diverted from theatre $[\ldots]$ and deliberately entertained by farce and comedy to turn them away from political and social problems'. ${ }^{62}$ Even the irresponsible exploitation of natural resources such as forests, for example, was seen as a consequence of similarly irresponsible behaviour of 'foreign imperialists' and 'capitalists' ${ }^{63}$ The 'new times' that were to begin with the annexation to Yugoslavia were therefore premised on 'doing away with the murky past and harmful consequences of the centuries-long enslavement' ${ }^{64}$

In mobilising support for the rejection of imperial legacies, post-World-War-II Yugoslavia could have of course drawn on a well established tradition of nationalist perceptions that saw the Habsburg and Ottoman empires as 'prisons of nations', and painted the past in terms of a struggle between South Slav national liberation movements and imperial oppression. ${ }^{65}$ However, Yugoslavia was itself a multinational

\footnotetext{
${ }^{60}$ Slovenski Jadran, 3 December 1954, 1.

${ }^{61}$ Primorski dnevnik, 3 September 1947, 1.

${ }^{62}$ Riječki list, 5 September 1947, 3.

${ }^{63}$ Riječki list, 17 September 1947, 2.

${ }^{64}$ Primorske novice, 26 November 1954, 1-2.

${ }^{65}$ For a critique of such binary oppositions between national liberation struggles and imperial structures, with particular reference to the nationalist politics in the Habsburg Empire, see Gary B.
} 
This is a pre-print version. Final version: Mihelj, S. (2011) 'Imperial Myths between Nationalism and Communism: Appropriations of Imperial Legacies in the Northeastern Adriatic during the Early Cold War', European Historical Quarterly 41(4): 634-56.

state, and had just experienced a period of bloody nationalist conflicts, many of them fought among members of Yugoslav nations themselves. In such a context, building on nationalist perceptions of imperial legacies alone could have been profoundly unsettling. Furthermore, the notion of a South Slav brotherhood of nations, drawn together by commonalties of race and culture and joined in the fight against imperial oppressors, was tainted by memories of failed Yugoslav nation-building in the interwar period. Interwar Yugoslav elites were heavily involved in an attempt to create a synthetic Yugoslav culture, based on the belief that Yugoslav peoples, despite being culturally, linguistically and religiously different, in fact constituted a single national whole. ${ }^{66}$ Yet this vision became intertwined with intra-Yugoslav nationalist tensions and came to be perceived by many non-Serbs as a thinly disguised attempt to Serbianize the country. Post-Word-War-II Yugoslav rejection of imperial legacies therefore had to be established on a footing that diverged from inter-war Yugoslav nationalist narratives of the past.

The break with inter-war Yugoslavism was achieved in two main ways. First, the emphasis on 'unity' was balanced by an emphasis on equality or 'brotherhood' of all Yugoslav nations. This joint emphasis on 'brotherhood and unity' constituted the main pillar of the communist Yugoslav civil religion, ${ }^{67}$ and helped disentangle the new Yugoslavism from any pretensions of creating $a$ unified Yugoslav nation. As such, it was believed to guard the new Yugoslavia against the 'mistake' purportedly committed by both its interwar predecessor and the Habsburg Empire, namely the attempt to forcibly assimilate all peoples into one single nation. ${ }^{68}$ The second element that was aimed at securing a clean break with pre-World-War anti-imperialist sentiments was the marrying of anti-imperialist struggle to class struggle. This gesture effectively brought the South Slav national liberation struggle in line with the international liberation struggle led by the working classes. According to the

Cohen, 'Nationalist politics and the Dynamics of State and Civil Society in the Habsburg Monarchy, 1867-1914,' Central European History 40 (2007): 241-278.

${ }^{66}$ Andrew Baruch Wachtel, Making a Nation, Breaking a Nation: Literature and Cultural Politics in Yugoslavia (Stanford: Stanford University Press, 1998), 67-127.

${ }^{67}$ Vjekoslav Perica, Balkan Idols: Religion and Nationalism in Yugoslav States (Oxford and New York: Oxford University Press, 2002), 94-105.

${ }^{68}$ Cf. Jović, 'Communist Yugoslavia,' 282-285; and Esad Zgodić, Titova nacionalna politika: temeljni pojmovi, načela i vrijednosti (Sarajevo: Kantonalni odbor SDP BiH, 2000), 40-41. 
This is a pre-print version. Final version: Mihelj, S. (2011) 'Imperial Myths between Nationalism and Communism: Appropriations of Imperial Legacies in the Northeastern Adriatic during the Early Cold War', European Historical Quarterly 41(4): 634-56.

Yugoslav myth of origins, this union was forged during the World War II, and found its expression in the Anti-Fascist Yugoslav People's Liberation Struggle, led by the Yugoslav Partisans. ${ }^{69}$ In line with this myth, the past anti-imperial struggles of South Slavs were now reinterpreted as struggles that were not led only by oppressed nations fighting anti-national regimes, but also by exploited working classes revolting against the bourgeoisie. Interwar Yugoslavia, went the argument, was unable to resolve these conflicts, and instead exacerbated them, largely due to continuing nationalist antagonisms between different national bourgeoisies and capitalist exploitation, but also thanks to the continuing influence of other 'forces of the past': feudal relationships, the Church, and continuing attempts of imperial forces to extend their spheres of influence..$^{70}$ Following this argument, the true solution to these conflicts could not be found solely in the continuation of the South Slav national liberation struggle. Instead, this struggle had to be intertwined with the international struggle of the working classes against both domestic capitalists as well as imperial forces. While references to South Slav and even pan-Slav brotherhood continued to feature in Yugoslav public discourse, including Tito's own speeches, they were normally used to mobilise support for the 'antifascist' and therefore 'anti-imperial' struggle, which was in essence supranational and not limited to South Slavs alone. ${ }^{71}$

Due to this union of national liberation struggles with the transnational struggle of the working classes, Yugoslav ant-imperial myths were based on a blend of nationalist and communist perceptions of imperial legacies. Hostile imperial forces, both past and present, were therefore not confronted simply with nations, but at the same time also with an international alliance of working peoples. This mixture necessitated a vision and division of the world that was markedly different from the one encountered in La Voce and Il Giornale. From the point of view of La Voce and Il Giornale, the world was divided primarily along geo-cultural distinctions, running along the concentric lines of nation, race and civilisation, and separating the democratic, liberal and civilised nations of the West from the totalitarian, communist and barbaric

\footnotetext{
${ }^{69}$ On the Yugoslav People's Liberation Struggle as a myth of origin see Perica, op. cit., 95-98; and Wachtel, op. cit., 133.

${ }^{70}$ Zgodić, op. cit., 40-42.

${ }^{71}$ Ibid., 68-72.
} 
This is a pre-print version. Final version: Mihelj, S. (2011) 'Imperial Myths between Nationalism and Communism: Appropriations of Imperial Legacies in the Northeastern Adriatic during the Early Cold War', European Historical Quarterly 41(4): 634-56.

nations of the East. In contrast, for the pro-Yugoslav newspapers, the main lines of division were cutting across, and thereby dislodging, geo-cultural alliances and divisions, pitting a transnational alliance of working peoples against an equally transnational coalition of imperialist, capitalist forces. Instead of being divided into two blocks, the world as seen through the lens of La Voce del Popolo was therefore divided into two fronts: 'the front of the imperialist instigators of war' on the one hand, and 'the huge front of peoples of all countries who want the peace' on the other hand. The latter included not only 'the invincible Soviet Union, the new Yugoslavia, Poland, Czechoslovakia, Romania, Bulgaria, Albania, the democratic forces of Greece and Hungary', but also 'the great majority of the people of America, England, France, Italy and all other countries not only in Europe, but across the whole world'. ${ }^{72}$ The FTT was fitted into the same interpretive framework. A commentary published in Slovenski Jadran saw it as 'an artificial creation, created out of imperialist hatred of the new Yugoslavia', ${ }^{73}$ while another, published in Primorski dnevnik, described it as 'a stronghold for various imperialist plans', designed to 'hinder the development of democratic forces [...] in Italy' ${ }^{74}$ Contrary to the vision propounded by La Voce and Giornale, the unjust settlement established by the FTT was not down to its failure to meet national principles, and therefore make polity coincide with nationality, but stemmed from its functioning as an obstacle to the anti-imperialist struggle.

The belief in the inextricable relationship between the anti-imperialist struggle of nations and the anti-imperialist struggle of working classes also came to the fore in interpretations of the Fascist past. Fascist policies implemented in the region were regularly presented as examples of the much broader phenomenon of imperialist oppression, directed not only at specific nations but primarily at working classes, regardless of their nationality. According to one article, Fascist Italy was responsible not only for 'preventing any education of Slovenians and Croatians', but also for denying education to 'the Italian working classes'. ${ }^{75}$ Due to this, anti-fascist resistance was inevitably a trans-national phenomenon, finding its expression in the 'Italo-Slav

\footnotetext{
${ }^{72}$ La Voce del Popolo, 15 January 1947, 1.

${ }^{73}$ Slovenski Jadran, 7October 1954, 1-2.

${ }^{74}$ Primorski dnevnik, 1 May 1947, 1.

${ }^{75}$ Primorski dnevnik, 3 September 1947, 1.
} 
This is a pre-print version. Final version: Mihelj, S. (2011) 'Imperial Myths between Nationalism and Communism: Appropriations of Imperial Legacies in the Northeastern Adriatic during the Early Cold War', European Historical Quarterly 41(4): 634-56.

brotherhood' and in the common fight against 'imperialist fascist oppressors'. An article published in Riječki list for example recalled how 'Italian imperial and fascist criminals $[\ldots]$ destroyed the Croatian Istrian press, $[\ldots]$ suppressed Croatian language and everything that was dearest and most valued to the Croatian people in Istria'. However, argued the author, this oppression did not lead to an all-out anti-Italian retaliation:
In such a situation one could expect that the struggle against Italian
Fascism, which was the most visible expression of Italy in this region, would lead to a struggle against all Italians, especially because Fascism only strengthened and widened the old Italian imperial politics in the Julian March. However, with the onset of the national liberation struggle the things here acquired a different appearance. [...] The great idea of brotherhood and unity of nations in the struggle against the common oppressor, for the common freedom and wellbeing, united both Italians and Croatians of Istria into a common front. ${ }^{76}$

Such official proclamations of Italo-Yugoslav brotherhood of course provide only a very partial insight into the struggles taking place on the ground, which often contradicted ideas of brotherhood and unity and continued to be fuelled by mutual suspicion and nationalist prejudices. Although local newspapers sporadically acknowledged the existence of inter-ethnic conflicts and prejudices, these acknowledgments were normally accompanied by interpretations that blamed the persistence of hatred and violence solely on prior exploitation. Together with proclamations of Italo-Yugoslav brotherhood, such justifications of inter-ethnic hatred by reference to prior suffering constitute variants of the discourse of negation and normalisation that has long dominated the collective memory and official historiography on the topic in the former Yugoslavia, and persists in the successor states. ${ }^{77}$ In explaining inter-ethnic violence and migration in the region during and after World War II, this discourse has either avoided the issue altogether, or tended to

\footnotetext{
${ }^{76}$ Riječki list, 2 March 1947, 2.

${ }^{77}$ For a synthetic overview and critical assessment of various interpretive approaches to the issue of inter-ethnic relations in the north-eastern Adriatic during and after World War II see Raoul Pupo, $I l$ lungo esodo - Istra: le persecuzioni, le foibe, l'esilio (Milano: Rizzoli, 2005), 187-204; for a critical review of approaches to the issue among Slovenian historians see Marta Verginella, 'L'esodo istriano nella storiografia slovena,' in Esodi: Trasferimenti forzati di popolazione nel Novecento europeao, ediated by Marina Cattaruzza, Marco Dogo and Raoul Pupo (Napoli: Edizioni Scientifiche Italiane, 2000), 269-278.
} 
This is a pre-print version. Final version: Mihelj, S. (2011) 'Imperial Myths between Nationalism and Communism: Appropriations of Imperial Legacies in the Northeastern Adriatic during the Early Cold War', European Historical Quarterly 41(4): 634-56.

resort to explanatory strategies that presented the movements of populations as largely voluntary, fostered by economic pressures and as such embracing not only Italians, but also Slovenians and Croats. ${ }^{78}$ Other factors, such as the discriminatory policies of the legal epuration of fascism conducted by the Yugoslav authorities in the region, or the persistence of nationalist prejudices, hatred and violence, were either ignored or explained away as legitimate reactions to suffering under Fascist rule.

Besides glossing over the everyday realities of interethnic tensions in the region, the overwhelming presence of appeals to transnational brotherhood and unity in local proYugoslav newspapers also provided little insight into the fissures appearing among both local and Yugoslav political elites at the time, especially in the period following Yugoslavia's expulsion from the Cominform in 1948. The rift between Tito and Stalin was couched in the rhetoric of anti-imperialism, with the Soviet Union now joining the range of imperial Others hindering the true progress of humanity. The reports on developments in the Soviet Union were now far from the glittering portrayals known from the immediate post-war years. Instead, the articles were warning against 'Soviet expansionism $^{79}$ and portrayed Soviet elites as the new imperialists who are enjoying a luxurious lifestyle while the living conditions of Soviet workers are deteriorating. ${ }^{80}$ Following the same interpretive framework, Triestine supporters of the Soviet Union were accused of misleading the proletarian mass in Trieste and supporting nationalist, imperialist and capitalist aims. ${ }^{81}$

The break with Soviet Union also marked the beginning of a slight shift in the relative weight of nationalist aspirations and class struggle, in favour of the former. Geocultural demarcations were now regularly appearing side-by-side with socio-economic ones. Particularly in the realm of foreign policy, Yugoslavia was beginning to adopt a new geo-political identity, positioning itself outside of the two 'imperialist' blocks, belonging neither to the East nor to the West. 'We,' argued Tito in a speech given in 1954, 'are following our own path into socialism, and we will not allow anyone,

\footnotetext{
${ }^{78}$ Pupo, op. cit., 192-193.

${ }^{79}$ La voce del popolo, 2 April 1954, 1.

${ }^{80}$ La voce del popolo, 15 June 1954, 3.

${ }^{81}$ Primorske novice, 3 September 1954, 2.
} 
This is a pre-print version. Final version: Mihelj, S. (2011) 'Imperial Myths between Nationalism and Communism: Appropriations of Imperial Legacies in the Northeastern Adriatic during the Early Cold War', European Historical Quarterly 41(4): 634-56.

neither those in the East nor those in the West, to make us stray away from this path' ${ }^{82}$ This liminal position allowed Yugoslav leaders to selectively draw on elements of imperial legacies associating them with both poles of the symbolic map, acting simultaneously as a bridge between, as well as a bulwark of, both the East and the West, while at the same time refusing to join either of them. Although declaratively rejecting its imperial past, Yugoslavia's new symbolic positioning was unwittingly appropriating one of the key elements of imperial imagery, namely the perception of the Self as the bulwark of civilisation, or alternatively as a bridge or crossroads of various civilisations. ${ }^{83}$ This symbolic positioning was to become particularly prominent from the late 1950s onwards, when it found its political expression in the Non-Aligned Movement.

A similar drift towards geo-cultural and nationalist frameworks was taking place also at the local level. Tito's rift with Stalin effectively contributed to further ethnic simplification of the north-eastern Adriatic: it weakened the proponents of the Slovenian cause in Zone A, as well as contributed to another wave of political purges among Italians in Zone B, this time directed at those disagreeing with Tito's line. ${ }^{84}$ Within Yugoslavia itself, nationalist principles were taking hold as well: Slovenian representatives were disappointed by the increasingly real prospect of 'loosing' Trieste, which among other things meant that Yugoslav borders would not coincide with the ethnic distribution of the Slovenian population. In the public realm, these stirrings became visible in occasional disagreements between newspaper commentaries written by Slovenian communist leaders, and official positions defended by Tito, ${ }^{85}$ as well as in the continuing insistence on the London Memorandum as an ultimately unjust, provisional solution. In a speech delivered by France Bevk, reproduced in Primorske novice, the Slovenian writer commended the

\footnotetext{
${ }^{82}$ Primorske novice, 2 April 1954, 1.

${ }^{83}$ For an examination of the symbolic positioning of the collective self as a bulwark, bridge and crossroads in Croatia see Ivo Žanić, 'The Symbolic Identity of Croatia in the Triangle CrossroadsBulwark-Bridge,' in Kolstø, op. cit., 35-76.

${ }^{84}$ Vida Rožac Darovec, 'Consequences of the Conflict between the Yugoslav Communist Party and the parties of the Information Bureau in the Free Territory of Trieste in 1948,' Annales: Series Historia et Sociologia 9. No. 2 (1999): 371-190.

${ }^{85}$ Jože Pirjevec, 'Londonski memorandum 1954,' in Vojna in mir na Primorskem, edited by Jože Pirjevec, Gorazd Bajc and Borut Klabjan (Koper: Založba Annales, 2005), 23-24.
} 
This is a pre-print version. Final version: Mihelj, S. (2011) 'Imperial Myths between Nationalism and Communism: Appropriations of Imperial Legacies in the Northeastern Adriatic during the Early Cold War', European Historical Quarterly 41(4): 634-56.

London Memorandum for being the best possible solution under given circumstances, and emphasised its role in maintaining peaceful relations with Italy. However, he also clearly signalled that the new arrangement of borders was not there to stay, since it did not coincide with ethnic distribution: 'if we look into the more distant future, we should not forget that unnatural borders, which unjustly cut into the body of a nation, cannot endure'. ${ }^{86}$ The rejoicing of local Slovenian newspapers at the annexation of Zone A to the Republic of Slovenia equally left no doubts as to the primacy of nationalist criteria in evaluating the London Memorandum. In a commentary published following the dismemberment of FTT, the Slovenian language newspaper published in Zone B, tellingly entitled 'the Slovenian Adriatic' proudly announced:

With the definitive annexation of Slovenian Istria to the Federal Peoples'
Republic of Yugoslavia, also our most immediate homeland Slovenia
obtained its window onto the world - the see. For long centuries we have
been violently and with deliberate thoroughness pushed away from the
coast, and denied recognition that this is our coast, that we have a right to it
and that it belongs to nobody else but us.

The growing presence of nationalist over communist frameworks signalled a trend that was to strengthen in the following decades.

\section{Conclusions}

Based on the material examined in the paper, we can conclude that the function of imperial myths cannot be reduced to nation-building alone, or understood solely with reference to nationalist principles of legitimation. Instead, we should distinguish between at least two main patterns of uses of imperial legacies, one organised within the nationalist framework of reference, the other within the communist one. The former was particularly clearly apparent in pro-Italian sources, which regularly referred to the Roman and Venetian past of the north-eastern Adriatic to support claims about its essentially Italian character, and hence the absurdity of Yugoslav rule in the area. At the same time, pro-Italian sources were also appropriating the Cold War rhetoric, and presented Italian rule in the region as essential not only for the fulfilment of Italian national interests, but also for the protection of Western

\footnotetext{
${ }^{86}$ Primorske novice, 15 October 1954, 1.

${ }^{87}$ Slovenski Jadran, 3 December 1954, 1.
} 
This is a pre-print version. Final version: Mihelj, S. (2011) 'Imperial Myths between Nationalism and Communism: Appropriations of Imperial Legacies in the Northeastern Adriatic during the Early Cold War', European Historical Quarterly 41(4): 634-56.

democracy against Eastern totalitarianism. Nationalist claims were appearing also in pro-Yugoslav sources, yet were nearly always presented as coextensive with the communist cause. From a pro-Yugoslav perspective, the anti-imperial struggle of nations was seen as intrinsically compatible with, and in fact integral to, the antiimperial struggle of the working peoples, regardless of nationality. After Tito's rift with Stalin, the emphasis on the transnational alliance of working peoples softened, giving way to a symbolic and ideological positioning that was more open to nationalist frameworks. Although remaining wedded to the communist anti-imperial struggle, this positioning also unwittingly fostered a revival of imperial legacies of perceptions, including in particular rhetorical tropes that saw Yugoslavia as a bulwark and crossroads of both the East and the West. 